\title{
Bottle gourd (Lagenaria siceraria) as an alternative of natural renewable source material in product design
}

\author{
Danieli Maehler Nejeliski ${ }^{1}$ and Lauren da Cunha Duarte ${ }^{2}$ \\ ${ }^{1}$ Universidade Federal do Rio Grande do Sul - UFRGS, Laboratório de Seleção de Materiais - LdSM, Av. Osvaldo Aranha, $n^{\circ} 99,6^{\circ}$ \\ andar, sala 607, Porto Alegre - RS, Brasil, danielinejeliski@gmail.com \\ ${ }^{2}$ Universidade Federal do Rio Grande do Sul - UFRGS, Escola de Engenharia - Departamento de Materiais - DEMAT, Av. Bento \\ Gonçalves, $n^{\circ}$ 9500, Porto Alegre - RS, Brasil, lauren.duarte@ufrgs.com
}

\begin{abstract}
The bottle gourd, scientific name Lagenaria siceraria, is the fruit of a plant of the family of cucurbitaceae that when harvested, if allowed to dry in the shade for some months, becomes hollow and with characteristics similar to wood. The plant is tropical and it adapts easily to any climate, the fruit has annual harvest, that is, its productive cycle is shorter than that of bamboo, for example, which lasts about three years. First of the plants domesticated by man, it had spread by all the continents before the human being, through the sea currents. Since then it has been used by people from various continents as raw material for the production of containers for food and beverages, musical instruments, floats, masks, among others. In the south of Brazil it is widely used for the manufacture of containers for the chimarrão, typical local drink. The accumulated knowledge about the material is empirical and the production of products, basically handcrafted, being rare the scientific researches studying the properties and the viability of its use for the production of other artifacts. Due to the properties it presents, it is a renewable source material with application potential in the design of new products.
\end{abstract}

Keywords. Lagenaria siceraria, renewable, product design

\section{Introduction}

The bottle gourd, scientific name Lagenaria siceraria, is the fruit of a plant of the cucurbit family, which also includes pumpkin, melon, watermelon and other widely used in food. The structures of the plants of this family are very similar to each other, with large leaves, growing near the soil. However, in relation to the fruits, it has very peculiar characteristics.

When the fruit ripens and is harvested, if allowed to dry in the shade for a few months, the placenta with the seeds dry and the fruit becomes hollow. The inner part of the shell acquires characteristics similar to wood and the outer skin, extremely thin and smooth, becomes impermeable and with a brown coloration (Fig. 1), and when polished it acquires a marked brilliance. Due to the hard shell, it is known as gourd in several regions of Brazil, being the term porongo most used in the southern region of the country.

The cultivation of the fruit is an important agricultural activity in the state of Rio Grande do Sul, where it is used for the manufacture of containers for chimarrão and handicrafts (BISOGNIN and SILVA, 2004). The fact of being basically associated with the production of artifacts of the local culture ends up restricting cultivation in other regions of the country, as well as its use as raw material for the manufacture of other products, yet it is the main source of income for dozens of small producers in RS (SILVA, 2005). Using it on new products such as containers for food and beverages, the demand for growing the fruit would increase, encouraging family farming as a whole.

Figure 1: External appearance of the bottle gourd.

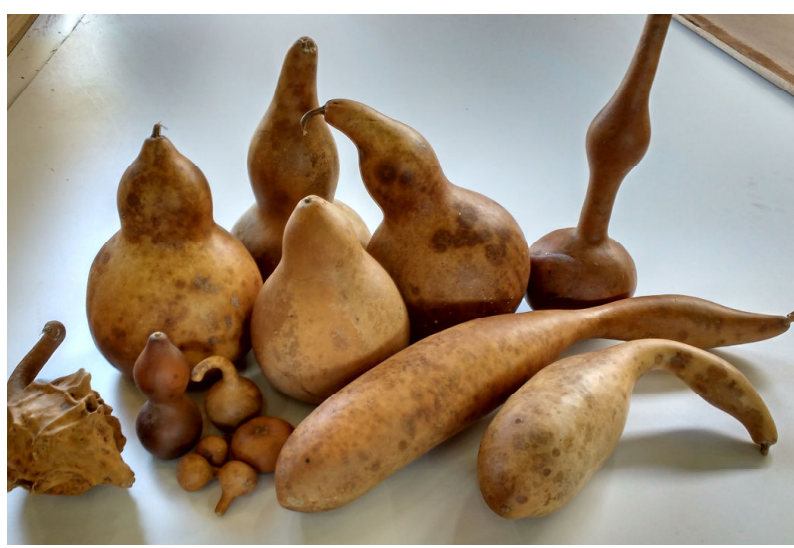

Source: by the author

The use of raw materials from renewable natural sources is becoming more than an alternative, but a necessity when the exhaustion of nonrenewable resources is certain and approaching each day. Biodegradable materials, which can be absorbed again by nature at the end of their life cycle, and which 
generate along this less waste of energy and residues, are a more sustainable option.

More specifically, in the context of design, the use of natural materials linked to the given territory, which carry the local and cultural symbols, contributes to the strengthening of the identity of products, communicating a higher perceived quality to users. Considering the massification of the products available on market, devoid of meanings, strategies of differentiation are extremely important in the design of new products.

\section{Origins of the oldest of domesticated plants}

The porongo belongs to the family of cucurbits (Cucurbitaceae), one of the most important families of plants used by man, providing food and fiber. These plants are related to the origin of agriculture and human civilizations, being among the first species to be domesticated (BISOGNIN, 2002). The pumpkin, the cucumber, the melon and the watermelon, important foodstuffs, and also the porongo, used for various purposes, belong to the family. Samples dating back to $11,000 \mathrm{BC}$ were found in East Asia. In the American continent, they were used from at least $10,000 \mathrm{BC}$ (KISTLER et al., 2014). Regarding specifically South America, the records date from 6,000 to $5,000 \mathrm{BC}$, however, there is no safe argument that can resolve the issue of the unusual bi-hemispheric distribution of the fruit (BISOGNIN, 2002).

In order to clarify the dissemination of bottle gourd in all continents and their origins, a group of researchers from the Pennsylvania State University, led by Logan Kistler, collected copies from all continents and sequenced 86,000 base pairs of DNA in the chloroplast and thus, were able to trace the branches of the family tree (Fig. 2) (KISTLER et al., 2014).

In the genealogical tree it can be observed that a common ancestor originates two others, A and B, from which all the other Asian and African variations are generated, respectively. A wild African specimen is the origin of everything, related in the first name of the list (wild Zimbabwe), and appeared approximately 250 thousand years ago. From it, the tree divides into two main lineages: one including the domesticated African specimens, and the other including the Asians.

The bottle gourds of the American continent share a common ancestor with Africans between 60,000 and 103,000 years ago, long before the first men who migrated to the Americas, which happened about 15,000 years ago. That is, the porongo arrived in the American continent without the interference of humans (KISTLER et al., 2014).

About 80,000 years ago, wild gourds grew only in Africa. The theory of transport by sea is one of the explanations for the spread of the species. The seeds may have been transported by sea, as computational models of sea currents indicate that it would take only a few months for the seeds of wild gourds to reach the American continent. The hard, impermeable shell would retain the seeds and, once out of the ocean, they would have sprouted. While Alaska would have been an inhospitable place for bottle gourds to grow, places with a tropical climate such as Florida, Mexico and Brazil would have been ideal (KISTLER et al., 2014).

Figure 2: Bottle gourd genetics

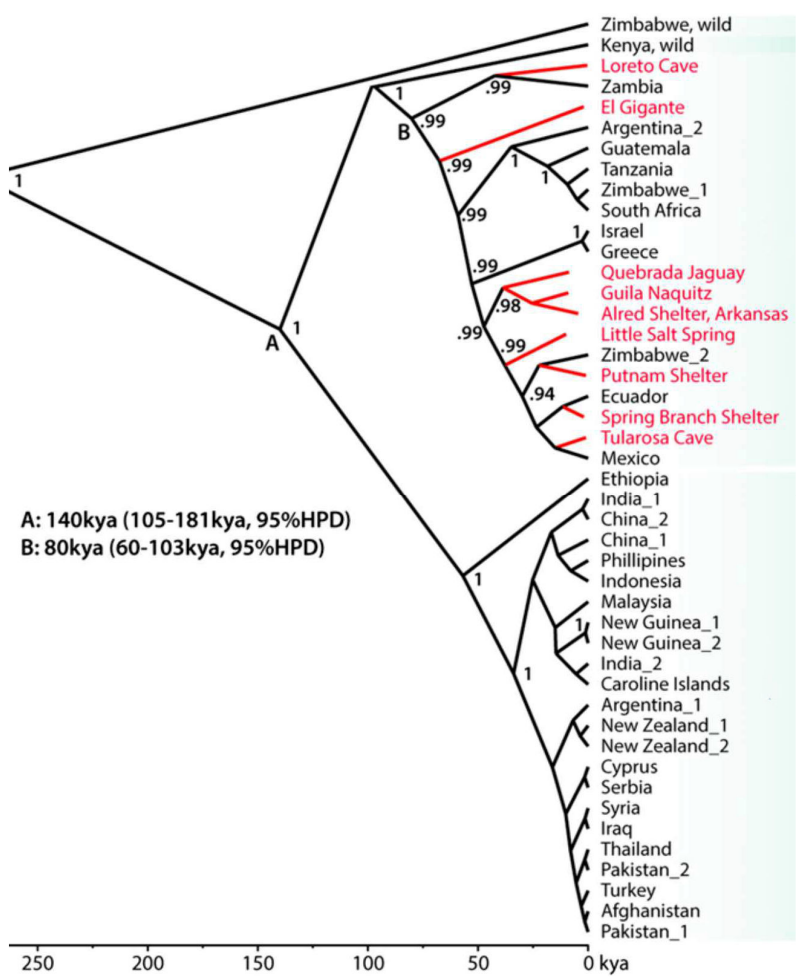

Source: Modified by Kistler et al., 2014

Africa was probably the first place where porongo was domesticated. Kistler et al. (2014) suggest that different groups of people may have come across different wild populations of the plant and selected those with the hardest shell to use as containers. Also in Asia the fruit is among the earliest domesticated plants, being brought by the first Polynesians to settle in New Zealand thousands of years ago. The bottle gourd was the first plant propagated from seeds by people in New Zealand soils (BURTENSHAW, 2003). The Maoris, a native people of New Zealand, use containers made from the fruit (Fig. 3).

In New Zealand the bottle gourd was also valued as a food plant. The young fruits resemble a zucchini and were cooked in hangi (cooked with natural vapours from the soil of volcanic terrain). However, it also provided the natives with ample range of containers, floats, musical instruments, ornaments and masks. Its use spread rapidly in Eastern Polynesia because there clay sources were scarce and over time the ceramic techniques were forgotten. Hence the importance of a plant that could annually produce a series of containers of different sizes (BURTENSHAW, 2003).

In Africa, in addition to being used in the production of food and beverage containers, its excellent acoustic properties have been exploited for thousands of years in the making of musical instruments. 
Figure 3: Kanohi father with bottle gourd containers, 1903

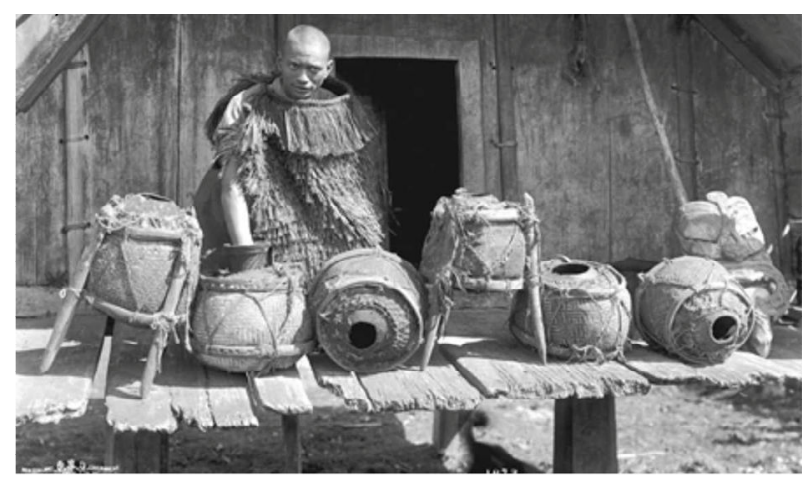

Source: Clarke, 2006

The fruit is used in the manufacture of a range of flutes, drums and stringed instruments in India, where it is used as a resonance chamber for the sitar and other musical instruments (BURTENSHAW, 2003).

With regard to the dissemination of the bottle gourd in South America, more specifically in southern Brazil, it is known that it was already known to the Guarani Indians in the year 1580, when the Jesuits arrived in the territory that corresponds today to the state of Rio Grande do Sul (LESSA, 1986). The chimarrão itself was a habit of the natives that the Europeans assimilated. But the Indians and the first immigrants of the region did not used the fruit only for the making of containers for chimarrão, they used it for the production of other containers, as can be seen in the permanent collection of the Parque Gaúcho museum, in Gramado / RS. The museum goes back to the origins and habits that formed the people of Rio Grande do Sul, and together with leather and ceramics, porongo was one of the main materials used in the production of everyday artifacts, such as containers for food (Fig. 4) and water (Fig. 5).

Figure 4: Guaraní Indians containers made from bottle gourds, food containers

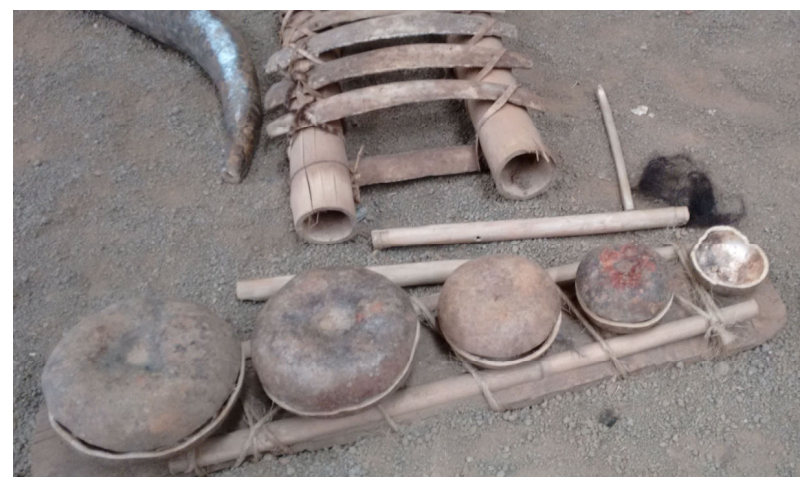

Source: Collection of the Parque Gaúcho Museum, 2015
Figure 5: Guaraní Indians containers made from bottle gourds, container for water

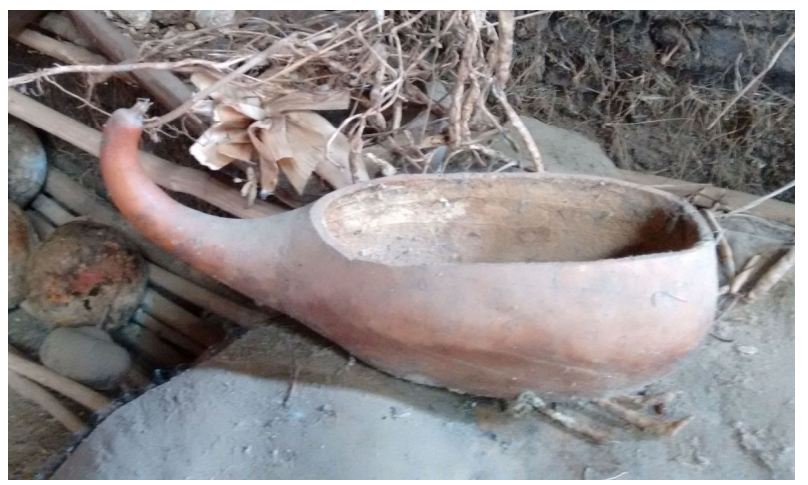

Source: Collection of the Parque Gaúcho Museum, 2015

The bottle gourd is part of the history and evolution of countless peoples and cultures. It has maintained its main aesthetic and functional characteristics intact for thousands of years, and continues to serve as a good raw material for the production of products today, as it did at the beginning of civilizations. Its triumph has long impressed scientists, among domesticated species, only the dog has spread more widely on the globe (KISTLER et al., 2014).

\section{From planting to fruit}

Regarding the planting, the informations found refers to the cultivation in the central region of the RS state. For the sowing of the fruit in the region it is selected seeds in the crop itself, by size and shape of the fruit, without any attribution to the plant, being a phenotypic selection of individual fruits. It is not known the origin of the populations used in the region (SILVA et al., 2002). The growth habit of the plant is climbing and remains low in the absence of a support structure, which has the advantage of greater control of the final fruit format (TREVISOL, 2013).

Regarding the plant structures, it has a well developed and branched root system, the stem is firm herbaceous, from which originate the leaves, shoots, inflorescences and tendrils. Regarding the leaves of the bottle gourd plant (Fig. 6a), they are usually simple, reniform, undulated, with entire margin. It is a monoecious plant, in which the male and female gametes are separated, the flowers have a white corolla with five petals (Fig. 6b). The fruit (Fig. 6c) is classified as a berry of the peponio type, because of its hard and resistant hull, the term gourd refers to the hard shell. As for the internal morphology, the fruit presents exocarp, mesocarp and endocarp (TREVISOL, 2013). 
Figure 6: Detail of the bottle gourd plant: a) leaves; b) flower; c) fruit

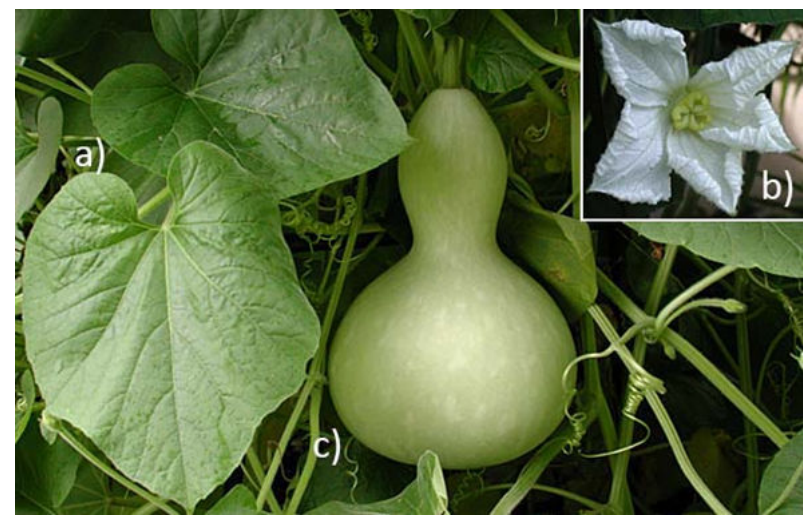

Source: Modified from POLITIS, 2014

The species Lagenaria siceraria has great variability of fruit sizes, hull thickness, length, symmetry, width and number of seeds. In order to classify the most recurrent gourd types grown in RS, Silva et al. (2002) suggest the following nomenclature (Table 1).

The positioning of the fruit in the soil, when small, must be vertical to form the base of the bottle gourd in the correct form. Fruits kept in the horizontal position can bend and lose quality as chimarrão container (TREVISOL, 2013). The harvest is performed after the natural senescence of the plant, in which the fruits are harvested and huddled in the shade to dry slowly. The drying process in the shade may take more than six months to allow the ripening of the material.

Table 1: Nomenclature for the different formats of porongos found in RS

\begin{tabular}{|c|c|c|}
\hline Illustration & Nomenclature & Format \\
\hline & $\begin{array}{c}\text { Compressed } \\
\text { Piriform }\end{array}$ & Pear shaped \\
\hline & Octoform & In format of the numeral eight \\
\hline & Halteriform & In dumbbell format \\
\hline & $\begin{array}{l}\text { Globular } \\
\text { Piriform }\end{array}$ & In format of the globe \\
\hline & $\begin{array}{l}\text { Eliptical } \\
\text { Piriform }\end{array}$ & In elipse format \\
\hline
\end{tabular}

Source: Adapted from SILVA et al., 2002

The green of the outer epidermis will disappear and the fruit will lose $90 \%$ of its weight with the evaporation of the water. When the bottle gourd is completely dry, the seeds will shake inside it (Fig. 7a) and the pulp will detach from the mesocarp (Fig. 7b).
Figure 7: Internal part of the dried fruit: a) Pulp, light-colored dry membrane; B) Seeds, dark spots on the bottom of the fruit

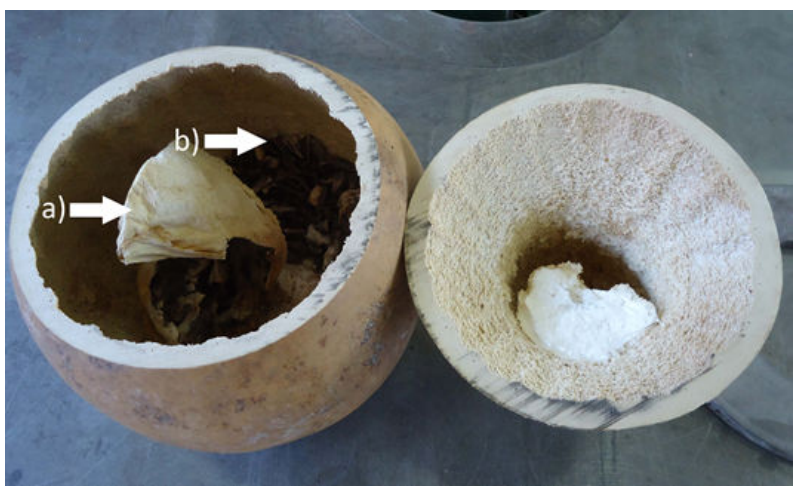

Source: by the author

The importance of knowing the harvest season is directly related to the quality of the fruit, since drying in the field after this phase increases the risk of necrosis of the material caused by fungi, with external and internal browning and loss of quality. In the research conducted by Trevisol (2013), the end of the cycle occurred at 195 days, the author developed a technique that relates the harvest point to the color of the fruit pedicel.

According to Bisognin et al. (1992), the average productivity of porongo reaches 12,000 fruits per hectare. The research carried out by Trevisol (2013) aimed at the management of the crop in order to increase the productivity and quality of the fruit. In the experiment performed by the author, the number of fruits per hectare varied according to the density of plants, being between 9,000 and 10,000 samples. At the end of the research, he concluded that the low yield of marketable fruits is related to the genetic variability of the species.

\section{From the fruit to the most varied products}

Bottle gourd is one of the oldest raw materials used by man for the making of artifacts. Being part of the evolution of humanity, it is understandable the great range of products made from it. Some artifacts are universal, common to all peoples who used them, such as containers, musical instruments, floats and masks, others are specific to certain regions. The combination of traditional methods of processing with modern techniques allows the production of differentiated products, such as luminaires, containers and other props made by hand from gourds (Fig. 8).

Characteristics inherent to porongo, mainly the shape and the resistance, always induced the man to use it as raw material in the manufacture of containers for foods and drinks, many of these still today are made in different parts of the planet. From the point of view of product design, it is important to observe the diversity of processes and techniques used in the manufacture of such artifacts, which vary according to the place where they are produced. 
Figure 8: Handcrafted products from India

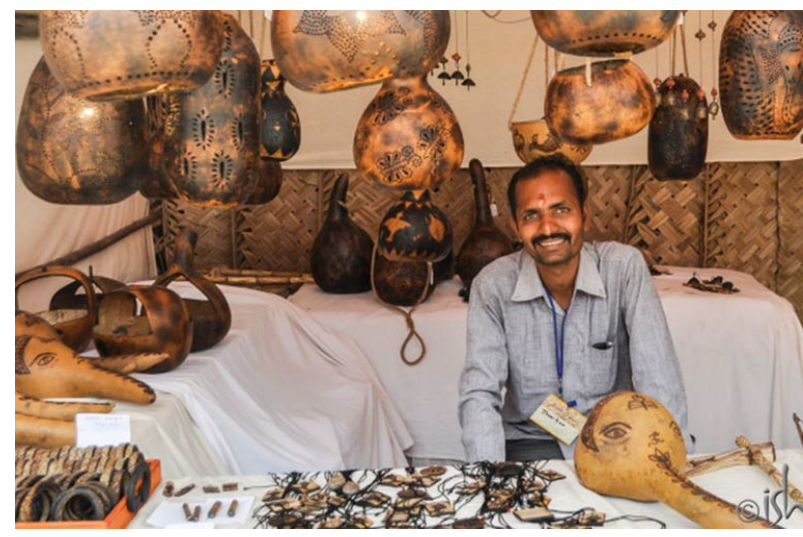

Source: ISHA, 2014

The fact that Africa is possibly the first place where the fruit has been domesticated may explain the variety and richness of manual crafts developed from the material.

The particularities of the fruit peel allow the application of various surface design techniques, such as embossing, dyeing and drawings, as well as the possibility of combining them (Fig. 9). The natural color of the outer shell is yellowish and darkens over time.

The Africans developed techniques that alter the original coloration, rubbing the fruits with leaves of millet it is obtained the color pink; With indigo, the color blue; And hanging them in a room full of smoke, they become darkened (POLITIS, 2014).

Figure 9: Various containers made from bottle gourds in Africa

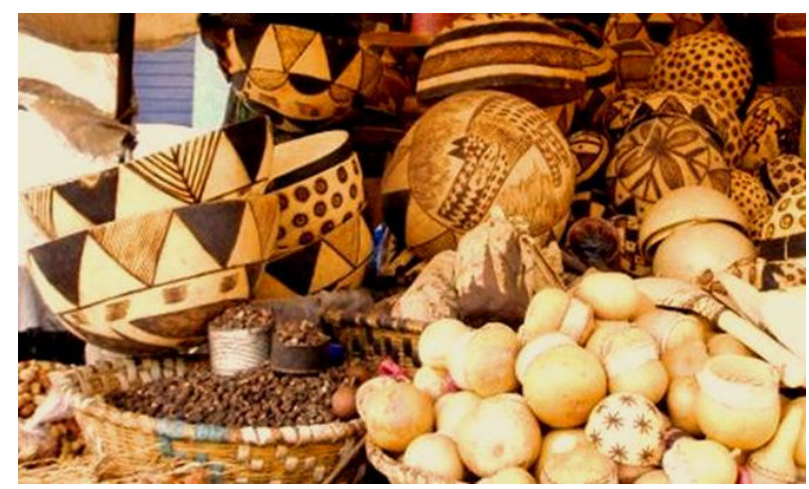

Source: Malika, 2009

The bottle gourd can be decorated by various techniques or different methods according to the tradition of the area, the main ones are scraping and pyrography. Scraping is performed on the surface of the material with a sharp tool, forming drawings when removing a thin layer. Pyrogravure is a technique where the most varied motifs on the surface of the material are engraved with incandescent iron, which causes the drawings to be generally dark in color, due to the burning of the material at the site (Fig. 10). Most of the time techniques are combined (POLITIS, 2014).
Figure 10: Containers made of bottle gourd decorated with pyrography

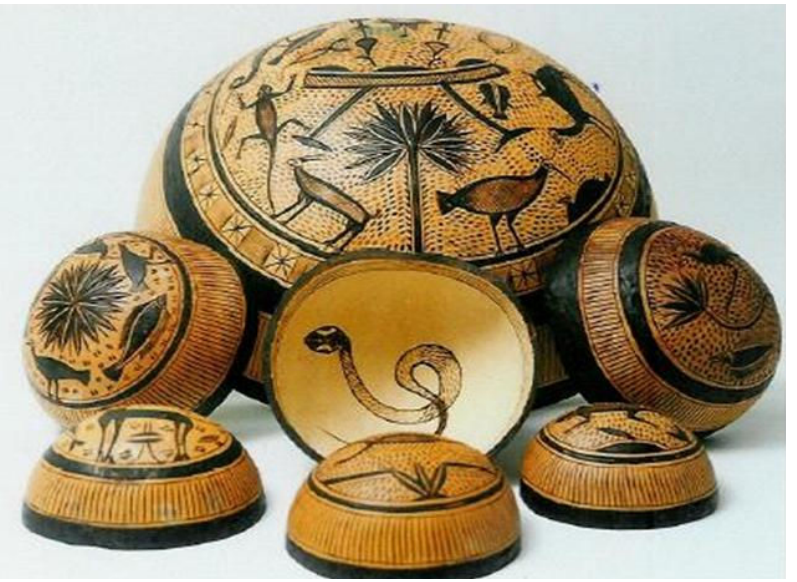

Source: HIWTC, 2013

In Latin America, more specifically Peru, Bolivia, and Ecuador, the bottle gourd has been used for medicinal purposes by Andean peoples for thousands of years. In the Inca culture, drawings representing folklore and symbology are applied to the external surface of gourds, which are passed from generation to generation (Fig. 11). This practice is still carried out today. The decoration of these fruits is an ancient tradition among the natives of South America, notably the central plateaus of Peru.

Figure 11: Decorated bottle gourds, Inca culture

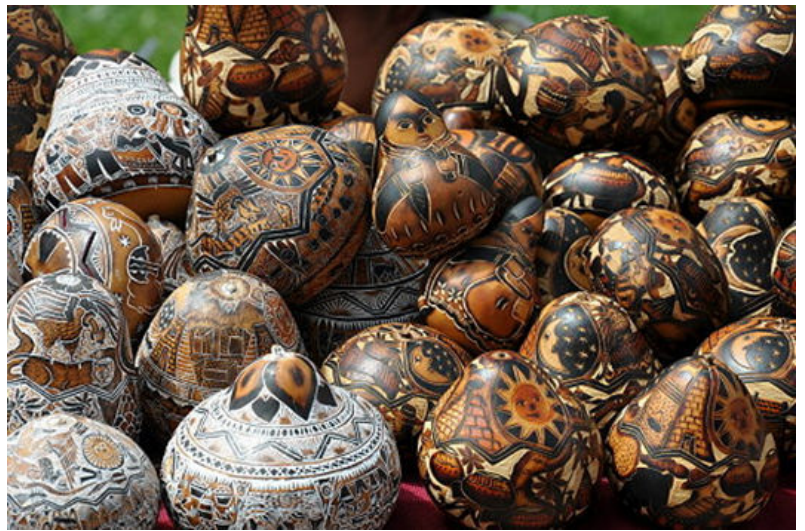

Source: Politis, 2014

The habit of chimarrão is not exclusive to southern Brazil. As a heritage of the native peoples who inhabited the region, even today, countries like Uruguay and Argentina are also drinkers. The chimarrão, as well as the habit of using the bottle gourd as container for the drink, is inheritance of the Guaranis Indians, natives of the territory in which today the state of RS is situated. From the process of obtaining the mate-herb for chimarrão until the manufacture of its container, little changed from what was done by the Indians centuries ago. The principle is the same, in the case of bottle gourd, only gained some adornments in differentiated materials to add aesthetic value. In Figure 12, some 
models of chimarrão containers, known as cuias, made from the bottle gourd.

Figure 12: Models of cuias used for the chimarrão in southern Brazil

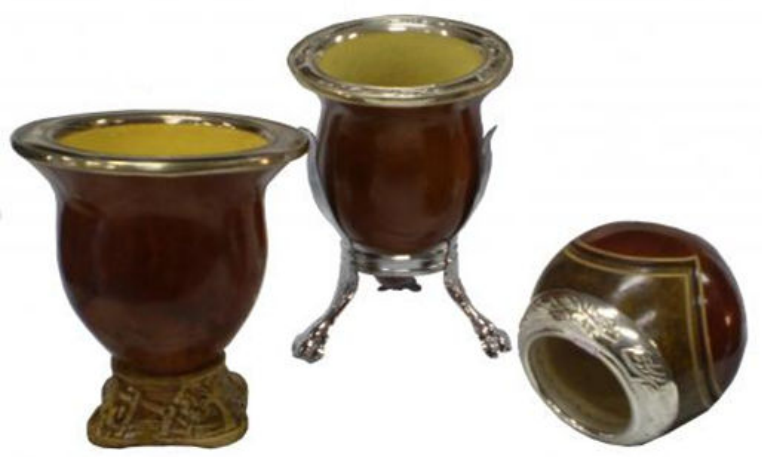

Source: TUNESILVA, 2014

The combination of traditional methods of processing with modern techniques enables the production of differentiated products, as is the case of the luminaires created by the Polish designer Przemek Krawczynski (Fig. 13). All his work has the bottle gourd as raw material . Each lamp is unique and the work is totally handcrafted. It begins with the design of the patterns, later the cleaning of the fruit is carried out and the engraving, sculpture, drilling and painting procedures begin. The base for the lamp is created and, finally, the luminaire is assembled.

Figure 13: Luminaire with dome produced by bottle gourd scraping

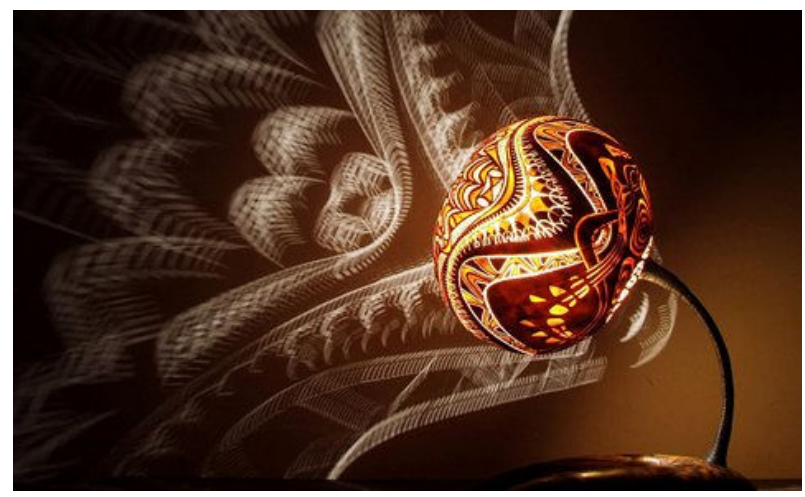

Source: KRAWCZYNSKI, 2014

The potential of the bottle gourd as a raw material in the production of products is a factor explored in many countries. It is interesting to note how a single material enables such a wide range of products, so many functional and aesthetic references to design work. Every people makes its mark, and the result is an incredible variety of techniques used. The bottle gourd can be combined with other materials, such as metals and resins, and it presents some consolidated manufacturing processes.

\section{Final considerations}

The bottle gourd can be found in different countries and continents, in each place with a different vernacular name. Because it comes from a plant that has spread to the continents before men, its history as a raw material for the production of artifacts is very old. Due to its great spread, the diversity of products made from it is very large. In the state of RS, Argentina and Uruguay it is used for the production of containers for the chimarrão, in Africa it is used for the creation of food containers, musical instruments, to cite just a few examples. The diversity of surface design techniques on the outside of the fruit is also very large, as is the list of artifacts made from it.

Due to its peculiar characteristics of shape, structure and surface, it is a differentiated natural material. Although it is an extremely ancient crop, from which numerous artifacts are produced, there is little scientific research for its use as a material. The objects made from the fruit are handcrafted, based on empirical knowledge. In the places where it is cultivated and processed, it is a source of income for the farmers who grow the plant and also for the artisans who manufacture the products from it. With a better use of the fruit in the making of other artifacts, the entire production chain increases, as well as the number of people benefited by the process.

The use of natural materials as a raw material in product design in general is a more complex work than the use of materials developed and processed industrially. When working with natural materials, automatically a network of people is involved, starting with those responsible for planting or even extracting the material from nature, through the initial processing, the artisans who create products from the raw material and by those who sell their products. It is an intricate process, but inherently more sustainable, because it creates a value chain that benefits all involved. In this sense, the valorization of the natural materials characteristic of each region, as well as the community involved, is just another possibility of design operation.

The use of natural materials from renewable sources as well as promoting local development is an alternative to non-renewable resources that are doomed to extinction. However, the feasibility of applying organic materials in the manufacture of products as containers for food and beverages, depends on some factors, such as the identification of basic properties, so that it can be characterized as material and potentiate its use in other products; and the application of treatments that may increase durability and extend the useful life of the material by virtue of its organic, degradable nature.

\section{Acknowledgments}

Laboratório de Seleção de Materiais - LdSM

Conselho Nacional de Desenvolvimento Científico e Tecnológico - CNPq 


\section{References}

BISOGNIN, D. A.; MARCHESAN, E.; AUDE, M. I. DA S. Densidade de semeadura e produtividade do porongo. Ciência Rural, Santa Maria, v. 22, n. 1, p. $15-$ 19, 1992.

BISOGNIN, Dilson A. Origin and evolution of cultivated cucurbits. Revista Ciência Rural: Santa Maria, v. 32, n. 5, p. $715-723,2002$.

BISOGNIN, Dilson A.; SILVA, André. L. L. A cultura do porongo. Informe técnico, ed. Pelo Departamento de Fitotecnia do centro de Ciências Rurais (CCR) da Universidade Federal de Santa Maria (UFSM), 2004.

BURTENSHAW, Mike. The first horticultural plant propagated from seed in New Zealand: Lagenaria siceraria. New Zealand Garden Journal, 2003.

HIWTC. Calabash bowls. Disponível em: http://www.hiwtc.com/products/calabash-bowls151198486-228988.htm. Acesso em 05 jul. 2014.

ISHA FOUNDATION. Tuma: decorative gourd craft of India. Disponível em: http://blog.ishafoundation.org/inside-isha/isha-yogacenter/decorative-gourd-craft/. Acesso em 06 jul. 2014. KISTLER, Logan; et al. Transoceanic drift and the domestication of African bottle gourds in the Americas. PNAS, vol. 111, $\mathrm{n}^{\mathrm{o}}$ 8, 2014.

KRAWCZYNSKI, P. Calabarte: art of light. Disponível em: http://calabarte.com/. Acesso em 05 jul. 2014.

LESSA, Barbosa. História do chimarrão. Porto Alegre: Sulina, 1986.

MALIKA, Fairly traded goods fro the Sahara region of West Africa. Calabash \& Gourds. Disponivel em: http://www.malika.org.uk/calabashgourds.htm. Acesso em 05 jul. 2014.

POLITIS, Michael. Bottle Gourd: a multi purpose utensil 10.000 old. Disponível em: http://www.valentine.gr/lagenaria_en.php. Acesso em 05 jul. 2014.

SILVA, André L. L.; et al. Coleta e caracterização morfológica de populações de porongo - Lagenaria siceraria (Mol.) Standl. - Cucurbitaceae. Revista Ciência \& Natura: Santa Maria, p. 91 - 100, 2002.

SILVA, André L. L. Germinação in vitro de sementes e morfogênese do porongo (Lagenaria siceraria (Mol.) Standl.) e mogango (Curcubita pepo L.). 2005. Dissertação (Mestrado em Agronomia) - Universidade Federal de Santa Maria, Santa Maria/RS, 2005.

THUNGA. African craft and design inspirations. Pottery \& Prescraft in Limbe, Cameron. Disponível em: http://thungablog.wordpress.com/. Acesso em 05 jul. 2014.

TREVISOL, Wolmar. Morfologia e fenologia do porongo: produtividade e qualidade da cuia. Tese (Doutor em Ciências). Escola Superior de Agricultura "Luiz de Queiroz", Piracicaba, 2013.

TUNESILVA. Cuias com bocal em prata e ouro. Disponível em: http://www.tunesilva.com.br/MostraProduto/39/Cuiascom-bocal-em-prata-e-ouro. Acesso em 10 dez. 2014. 